\title{
Toward a Collaborative Housing Initiative: The Role of local authorities
}

The different forms of collaborative housing, their possible effects on the housing market and urban development processes have gained importance in housing policy and city development debates in many European countries. A shift towards the growing acceptance and promotion of more collaborative housing concepts can be observed in the case of numerous cities. However, the precise process of co-creation and comanagement can be widely different, depending on the exact relation of stakeholders to each other, the legal, economic and institutional environment, the level of business interests involved, and very importantly, the role local authorities are willing to play in the process. Following three countries and highlighting cases in each of themGermany, Hungary and the United Kingdom - the article aims to give a better understanding of how this co-creation process is influenced by the governance concepts and practices of local authorities, arguing that their support becomes even more essential if the financial resources are scarce or the national legislation -including the laws regulating the housing market - is not supportive.

\section{KEY WORDS}

Local authorities, collaborative housing, market niche, Hungary, UK, Germany, postSocialist housing market

\section{Introduction}

Collaborative housing has become an increasingly important phenomenon in many Western and Northern European countries in the last two decades, providing an opportunity for new bottom-up models of housing construction (including complex refurbishments) and a more flexible approach to housing development. These models also challenge in different ways the housing policy and planning cultures in their respective countries (Tummers 2015a). Parallel to this the idea of collective housing and the innovative construction types attached to it have generated much debate in housing studies, focusing among others on the possible advantages and disadvantages - both public and private - provided by them (see among others Lang et al. 2018, Tummers 2015b; Ache and Fedorowitz 2012, Fromm 2012).

Some studies have shown that collaborative housing offers new possibilities to regenerate urban areas, integrate disadvantaged social groups and provide partial solutions to problems presented by ageing societies; or create sustainable development models for urban neighbourhoods and support the development of vibrant neighbourhoods (Droste 2015; Fromm 2012; LaFond and Tsvetkova 2017). There is further exploration going on about their possible influence in creating bonds between refugees and the local population, by providing uncontested space for integration and social bonding (Czischke and Huisman 2018). On the other hand, research also suggest constraints. It seems that so far collaborative projects have remained largely accessible to more affluent population segments, and it is a challenge to make them affordable for lower income population groups even in supporting local contexts (On the example of 
Hamburg and Gothenburg see Scheller and Thörn 2018). This finding has been corroborated by a new quantitative research on the example of Denmark that shows cohousing residents being privileged both in a socio-economic and an educational sense (Jakobsen and Larsen 2018).

Collaborative housing projects are manifold, but they can be described along a few general characteristics: they are typically non-profit, built following the initiation of the future inhabitants (although here we can see the growing importance of SMEs), and are planned in a cooperative way (Twardoch 2017). To reflect this multi-faceted nature of the initiatives the article adopts an umbrella definition for collaborative housing, created originally by Fromm and applied in their conceptualizing article by Lang et al. (Fromm 2012 and Lang et al. 2018).Thus collaborative housing includes all housing forms that operate with shared facilities, and/or where residents participate in the process of design. This encompassing definition includes both, often interlinked aspects of collaboration: that of planning (co-creation) and use (co-habitation).

Numerous projects narrate how both creating and operating collaborative housing is difficult, and many endeavours are met with barriers. Often, the process takes long, even up to 10 years. One actor, whose support is crucial in paving the way for success, and whose support can shorten significantly the time for realisation, is the local government. Operating locally, it can be instrumental in supporting decision making for collaborative groups, as well as providing support to overcome legal queries and facilitating access to land for these endeavours (see on the example of Austria Lang and Stoeger 2017). Despite its significance, there has been less focus on its role. Thus, the article aims to analyse the local governments' role in supporting the successful establishment of collaborative housing projects in their territories. It defines 'succesful' as it is realistic for residents to start such projects, participation is not restricted to certain groups, and collaborative housing is used as part of the local government's agenda for urban development and housing policy.

The authors select three countries - Germany, Hungary and the UK - where the local governments' role in supporting the realisation of collaborative housing projects is compared. The case study countries differ both regarding the level of penetration of the collaborative models in their housing markets, and the role local governments play in supporting them. The paper relies on the combination of desktop research and the conduct of semi-structured qualitative interviews with both locally relevant stakeholders in all three countries and residents/future participants of collaborative housing projects. The interviews have been conducted in the course last four years since $2015 .^{1}$

First the paper outlines theoretical considerations behind the possible roles local governments can play in supporting collaborative housing. Then it goes on to describe the three countries in three separate sub-chapters. In each of these the paper provides the general national context briefly, outlining the national/regional framework for the support of the collaborative housing projects, and then focuses on selected cases of collaborative housing. It does so because the political/governance context is crucial in determining how successful the collaborative processes can be (Beaumont and

\footnotetext{
${ }^{1}$ The interviews for the case in Hungary and the UK were partially conducted for the PROFICIENT project, financed by the EU's 7th Framework program.
} 
Nicholls, 2008). The individual country analyses is followed by a conclusion, where findings and a brief comparison between the countries is presented.

\section{Collaborative housing and the role of local governments}

Collectivism and collaboration in housing provision as a trend go against more traditional residential development models and top-down policies and allow (future) residents to play a more significant role and engage in a process of co-production with the developers/housing providers (Czischke 2017). They also allow the development of a relationship based on more equal footing between residents and local governments. Amid the undergoing deep social changes many local governments started to endorse the diffusion of collaborative housing as an alternative housing model. The growth of single person households, the growing environmental concerns and the still lingering financia1/social consequences of the economic crisis all contribute to this increasing support (see on Germany Ache and Fedorowitz 2012 or on the UK Lang and Mullins 2015 and Moore and McKey 2014). But the support for collaborating housing projects and the way local authorities deal with these projects are also part of the changing process of the wider field of governance, re-evaluating the municipal role in terms of urban development. This change also means an increasing demand for participation and the need for custom-made solutions from the side of residents. From the side of the local governments it involves the need to bring together multiple stakeholders in the process of decision making (Ansell and Gash 2007; Tummers 2015a).

Views and assessments of these collaborative governance processes are rather divergent in general. On the one hand it has been argued that the changes regarding the governance system, the broadening of participation and the displacement of decision making creates a loss of accountability on the side of the elected local authorities (Swyngedouw 2000) and can lead to the selected empowerment of groups (Mayer 2000 quoted by Sorensen and Sagaris 2010). On the other hand, cases under very different legal and institutional circumstances and differing traditions of public governing demonstrate that well-financed and well-organised programs have the capacity to create appropriately functioning structures for collaborative processes and successful local/neighbourhood empowerment (Abers 1998; Fagotto and Fung 2006).

Specifically, in supporting collaborative housing projects the role of local governments can be manifold. The level of local public interest can be context dependent, subject to the exact form and values of each housing initiative. Collaborative housing projects are often contextual, specific and situational (Boonstra 2015), requiring somewhat different support from the local governments and fulfilling different needs in each case. Projects of this nature often face barriers and difficulties both regarding the initiation process and during implementation. Their success depends on smooth cooperation among many actors at numerous levels and even occasional unanimous decision making from the (future) residents. Financial constraints also play an important role, as acquiring adequate plots and buildings has become increasingly difficult in the context of surging real estate prices. Local governments can become crucial facilitators and aids in all of these aspects, and can play a central role in helping people to arrive to joint decisions. 
The possible role local governments can (and should) play in supporting the collaborative housing projects is also determined by the various legal/regulatory frameworks. The realisation of collaborative housing projects takes place in different contexts of co-creation and co-habitation across Europe (see on the particular arrangements among others Boelens and Visser 2011; Bresson and Labit 2017; Verstraete and De Decker 2017; Lang and Mullins 2015) which influences the ways how local governments can support them. In some countries many collaborative housings are in rental ararngements (e.g. the Centraal Wonen in the Netherlands) while in others cooperative ownership has become a widely preferred legal form to create a non-speculative form of housing (e.g. in Germany). Finally, some are privately owned either as a condominium or as a business company. The latter becomes important in countries with little cooperative presence like the UK or Hungary.

Generally, the need for local government support for the collaborative housing initiatives grows as the co-creation and community-driven elements become stronger, or with the increase of integrative and ecological elements. Without help, many of the social aims must be dropped, and additionally either the planning time or the financial commitment from the residents increases substantially (Geröházi and Hegedüs 2016).

\section{Collaborative housing in practice: examples from Germany, Hungary and the UK}

In the following section, examples from Germany, Hungary and the UK show how the process of establishing/supporting collaborative housing projects varies across Europe, depending on the local governments' openness to engage in more participative approaches, as well as the availability of local and national supporting structures. Germany was chosen as an example for a country where a surge of the collaborative sector can be observed: numerous projects have been realised under different regional legal and regulatory frameworks, and with varying levels of community involvement (Ache and Federowitz 2012; Droste and Knorr-Siedow 2014). Hungary was chosen as a country where collaborative ideas in the housing market are only starting to gain ground (Geröházi and Hegedüs 2016). The UK, selected as third example, shows that a strong political discourse on the importance of community empowerment, is not sufficient in itself for increasing the amount of realised co-housing projects (Lang and Mullins 2015; Scanlon and Fernandez 2015).

For all three countries the selected case studies look briefly at:

1) the strategies local governments follow to support collaborative housing initiatives; 2) what (if anything) local governments want to achieve by it; and

3 ) if they are supported by other actors in doing so.

For each country a brief description of a co-housing case is provided, a the details of which are found in the project sheets at the end of the article.

\section{a. Germany}

Although collaborative housing has become a major source of discussion and activism in numerous German states and cities, its penetration is unequal across the Federal 
State. Co-housing is especially siginificant in cities like Tübingen, Freiburg, Munich, Hamburg, Berlin and Leipzig. In these places it would not have become the phenomenon it is today without local governments embracing the idea of new, bottomup initiated participatory planning methods and considering collaborative housing as a possible means to fight locally the steeply rising land and building prices.

To assess the role of local governance for the development of collaborative housing in Germany, it is important to understand that following the principle of subsidiarity, local government structures and housing funding schemes differ within the sixteen German states (Länder), including three city-states (Berlin, Hamburg and Bremen). The Länder and local authorities have substantial power regarding the implementation of public policies, the local authorities being responsible for about three quarter of public investment, including housing issues. Both regarding the legal framework and funding, the municipal governments and structures of governance in (mostly larger) cities play -a crucial role wherever collaborative housing is successful in Germany. The legal framework is provided by the national level of but implemented on the lower ones in a strong cooperation between the federal (State), regional (Länder) and local (Municpal) levels. This holds also true for housing funding structures: National housing funding has been abandoned in 2000 , only the severe shortage of social housing led to specific funding for this market sector since 2018. Based on their general budget and this specific funding, the Länder develop their own housing funding schemes. At the same time, both national and Länder ministries have developed programmes to support specific forms of collaborative housing (e.g. the Ministry for Family, Senior Citizens, Women and Youth on the national level and the state of North Rhine Westfalia).

Rooted in a political will to re-enforce community-oriented housing culture in a longterm affordable stock, cooperation has been on the agenda of both local governments and the so-called German 'housing project landscape' (Wohnprojektelandschaft) (BBSR 2007, Droste 2015). Having its roots in dissident forms of housing and in cooperative housing, collaborative housing has become a middle-class project in the late 1990s. Since 2000 is has become an option for many across different generations, milieus, income strata and locations. The diversity of this stock aggravates a provision of robust data, not least due to the fact that often projects lose their public visibility after the moving-in-phase. ${ }^{2}$ In national housing statistics, it is both represented in the $22 \%$ (not necessarily collaboratively organized) shared properties of the overall housing stock and in the traditional collaborative housing stock, representing roughly $10 \%$ of the rental sector and 5\% of the overall housing stock (BBSR 2016; Kott 2016).

The collaborative housing projects central to this article are concentrated in a select number of cities, mainly Berlin, Hamburg, Tübingen, Munich, Freiburg and Leipzig. They are mostly small cooperatives and other projects that have been developed since the early 1990s. This diverse market section of between roughly 1.000 and 3.000 projects is housing an estimated minimum of 30,000 residents (BBSR 2007, Droste 2015). It emerged above all in new building and reflects a wish to live in high quality building, providing spatial design and functions that are different from the mainstream blocks of flats building. As a 'social concept', the projects intertwine with creative milieus, do-it-yourself culture, social initiatives and care-concepts for the old and handicapped. Rooted in a political will to re-enforce community-oriented housing

\footnotetext{
${ }^{2}$ Sources: Own research 2011-2016, student research BTU Cottbus 2016.
} 
culture in a long term affordable stock, cooperation is on the agenda of both municipalities. Nevertheless, the so-called German 'housing project landscape' (Wohnprojektelandschaft) has many urban 'collaborative hotspots' but also urban and rural regions where collaborative housing is less present.

The abandonment of Self-Help Project Housing Funding in Berlin as well as Social Housing Subsidies all over Germany before the turn of the century, left public support consisting mainly in knowledge-transfer and networking infrastructure. However, since about 2011 and following research-based knowledge on the positive socio-spatial and housing cost effects of collaborative housing (BMVBS 2007, Netzwerk Selbsthilfe 2010), cities with an increasingly unaccessible housing market turned towards concept based fixed-price land allocation policies. Affordability, inclusion-oriented concepts and contributions to culturally emancipative, multifunctional neighbourhoods have become key criteria for public-private cooperation.

In this context Tübingen is the first relevant example where collaborative housing has become a model for yrban development in a very tense housing market. In the first phase, the city promoted collaborative housing based on the conversion of old military (Französisches Viertel) or industrial (Mühlenviertel) sites, based on a set of regulations: It limited the sale of the brown-land sites to self-using owners and collaborative projects and made the inclusion of work-places and social infrastructures into the housing projects a binding obligation. A city owned development-company supported the collaborative housing projects in renewal and new building with high quality public space. Furthermore, the projects were promoted to include assisted housing for the aged and handicapped.

in 2016 when Tübingen became one of the four most expensive German cities. The municipality entered a new phase of coproduction of the city with collaborative housing actors, through acquisition of inner city private land for 12 urban development areas. Moreover, construction of 2000 affordable flats for refugees became necessary. In this context, a new actor emerged: a citizens' housing company (Bürgerbaugesellschaft; Neue Nachbarn KG), referring to a model project in Französisches Viertel. Within the next ten years, $75 \%$ of its units will be rented out to refugees. (Hartmann/Burkhardt 2015; expert interview with Axel Burkhardt 2018).

Besides local government support and public-private cooperation, the German condominium and housing cooperative laws are important conditions for the diversity and increase of collaborative housing. This legal framework not least ensures the projects' credibility with the traditional banking and financing sector. Since the early 2000s, specialised banks have emerged, dedicated to funding ecological and non-profit enterprises and housing at comparable conditions to mainstream mortgage banks. Three organisations: German Trias Foundation, the Swiss Edith Maryon Foundation and the Mietshäuser Syndikat providing reliable lease-hold models to less affluent groups and social inclusion-oriented initiatives. This experience contributed considerably to the credibility of co-housing. Whereas the foundations allow individual property, the Mietshäuser Syndikat systematically withdraws buildings from housing speclation ${ }^{3}$ as umbrella association of currently 135 projects tenement.

\footnotetext{
${ }^{3}$ For more detailed information see the https://www.syndikat.org/en/
} 
Finally, in some regions, collaborative housing have been included in social housing funding schemes based on its potential for cost reduction. The public housing subsidy strategies in Munich and the city's cooperation with the cooperative wagnis e.G. ${ }^{4}$ show how combined collaboration and funding structures help to achieve affordability in an extremely dense housing market:

Munich has 40 local housing cooperatives, owning about 35.000 units (app. 5\% of the local rental stock). To respond to the increasing demand for cooperative housing, they depend on the city's four pillar-based support:

1) The city includes 30-40\% cooperative housing and community oriented building groups (Baugemeinschaften) in new housing development areas.

2) It provides a cooperative housing funding programme (München-ModellGenossenschaften) and

3) pays the cooperative shares (Genossenschaftsanteile)for income groups being eligible to public housing benefit or public housing funding.

The fourth pillar is a two phased concept-based allocation of publicly owned plots (Konzeptverfahren), increasingly based on long-term leaseholds. This leads to a strong cooperation between the city and the cooperatives as main stakeholders. Furthermore, cooperation with social carriers and volunteers' networks on the neighbourhood level has been identified as key instrument to enforce the city's and cooperatives 's objectives (BBSR 2016). A case illustrating the effects of this strategic cooperation is wagnis e.G.. The number of its members increased since its foundation in 2000 from 21 to more than a thousand; it owns 425 units in five ecologically and socially sustainable building projects (wagnis 1/2/3/4 and wagnisART). The city allocated the plots for these projects in new housing areas, to safeguard socially integrative and mixed-functions development. Each of the projects offers a variety of flat-types, community-oriented shared space, social infrastructure and small retail open to the neighbourhood. (Ring 2016 / TUM 2017; see case-study p. xxx).

Collaborative housing in Germany could not be where it is today without the middleclass projects on the one hand and a strong mix of dissidence with regards to the capitalist housing market on the other hand, whose realised examples tell a convincing tale. Also, continuous political lobbying has led to the inclusion of the sector into public housing policies, contributing to the sectors' growth.

Comparing the strategies of Tübingen, Freiburg, Munich, Hamburg, Berlin and Leipzig, three pillars seem essential to achieve a win-win situation for all stakeholders (including individual users/the city society): First, a dialogue on equal terms between the different stakeholders, providing space to negotiate the goals of the involved and the resources to achieve these in co-production. Second, a long term and transparent land allocation strategy, taking in account the economic capacities and social capital of the target groups - up to cities buying land reserves from the private sector or providing public replacement mortgage outside the mortgage market. Third, willingness of collaborative housing actors in need of public support to take on socio-spatial responsibility in neighbourhood development (BBSR 2019; Droste 2015). In addition, in most cities with a relevant dimension of collaborative housing, intermediaries (small SMEs and NGOs) help in translating the needs of collaborative projects towards the

\footnotetext{
4 The cooperatives name may be literally translated into "take on the risk", 'e.G.' means 'registered cooperative', according to the German cooperative law.
}

Commented [A1]: Do yo mean it is mandatory to involve NGOs or recommended? 
municipalities, providing professional advice and facilitation. Also, architectural firms and small scale developers have specialised in facilitating and playing an intermediary role for initiating collaborative housing processes. Both types of professional actors foster collaborative housing friendly policy implementation on the local level.

\section{b. Hungary}

The Hungarian collaborative housing scene is vastly different from collaborative housing practice in Germany. As the case study will demonstrate, municipalities are typically not outright against the collaborative housing projects, they rather seem to be reluctant observers. This is also related to the fact that new governance approaches and bottom-up participatory models are not very widespread in Hungary, and participatory processes are typically restricted to higher educated/higher income groups (Ferenczi 2015). Establishing stable collaborative housing in today's Hungary is difficult. ${ }^{5}$ There are cohabitation initiatives, typically based on short and mid-term renting of single large units with 5-6 rooms, usually with fast changing communities. These small-scale communities are as a rule temporary arrangements - forming during or right after university, consisting of young people before they settle and start a family. Real challenges arise when some of these communities aim to remain together well into their adult life, trying to find a more permanent solution for their housing needs. In the overwhelmingly owner occupied environment of the Hungarian housing market purchasing a dwelling is not only the most important and most costly household decision, but the central budgetary point of family strategies. This leaves little room for experimenting or accommodating the rising costs that are the result of collaborative arrangements (Hegedüs and Szemzö 2015). This is further aggravated by a relatively rigid financial sector preferring individual households and only reluctantly providing loans to groups or associations.

Local governments are the actors who could change this dynamic, as they are legally responsible for housing and urban planning issues on their territories. Following the decentralisation after 1989, local governments had major responsibilities in spatial planning, the provision of social housing, the provision of primary and secondary education, health care and social services. Although the division of roles between different government layers has been changing since 2010, the issue of social housing as well as planning remained in local hands. Nevertheless, few local governments engage in housing constructions, and social housing provision is often regarded as a costly and unwelcome task, whereby many local governments try to minimize the public stock in their hands (Hegedüs 2013).

Importantly, local governments are typically not antagonistic towards collaborative housing. Expert interviews suggest that the idea itself seems thought provoking and interesting, but the agenda is never important enough to really provide support. ${ }^{6}$

\footnotetext{
${ }^{5}$ There was a pioneer attempt to establis h co-housing already between 1979-1989 in the city of Miskolc inhabited by local architects, but no followers showed up. (Babos and Lukács, 2014) On the other hand in the 1970s and 1980s, thousands of units were built based on the initiation of the future owners and guided by typically lawyers. This was a cons equence of the housing shortage. (Hegedüs and Geröházi, 2016)

${ }^{6}$ One exception for a more interested local government is district 14 in Budapest, who have won an Urban Innovation Action application, and will build a municipal co-housing. https://www.uiainitiative.eu/en/uia-cities/budapest However, so far little is known about the project, the contours of the programs are just taking shape.
} 
Conversations with municipal representatives, chief architects and representatives of real estate management companies from Budapest show that their engagement could be either propelled by value gains in either the field of housing or in urban development side. ${ }^{7}$ Regarding the housing market, municipalities mostly see their main role in the housing market as the (often reluctant) actor responsible for providing social/affordable housing. ${ }^{8}$ Urban development motivations could be more rational in the Hungarian context, given the that co-housing projects can bring in new life and investments into distressed areas. Since territorial development is one of the main issues for local governments, it is surprising that so far, this angle has not drawn more attention or interest.

Rákóczi Kollektiva (RK)'s history fits well into the collaborative housing scene of Budapest and Hungary. Currently composed of 7 members, they are finally settling for a family house - purchased from private, individual loans and savings in 2018. (See the case study description) This is the end of a long journey, during which the group has been trying to find permanent solutions for almost a decade. Established after moving out of university dorms close to finishing the studies, they have been working on establishing permanent building accommodation as a rental cooperative since 2011.

As part of their efforts to realize their goal, RK has contacted different municipalities in Budapest - including the City Municipality (Budapest level) and all district municipalities (there are 23 of them). However, despite some initial positive responses, the talks always stalled. In case of the City Municipality, which not only showed interest, but also owns appropriate and unused buildings, the different departments shied away from making a final decision, and the responsibility was pushed to the highest level, effectively killing the negotiations. In case of districts it was often the question of time and money. In one case the empty building in question was part of a bigger complex, the development of which would still take years. On another occasion, with a supportive district mayor, the available empty kindergarten building was both too costly to refurbish and too large for the community and anyhow the decisions on it would have taken years. They also tried to contact banks, and take a mortgage jointly, but have failed so far, making them solely rely on the bankability of three members.

The analysis of the interviews and the wider Hungarian context show that reasons behind the lack of interest from the local government's side can be traced back to three distinctive, but equally important phenomena. First, the particular governance structure of intricate responsibilities creates a situation where, even if a single decision maker would support it, real support often strands in the bureaucratic strategies aimed to minimize personal responsibility. Even if there is an obsolete school building, legal and bureaucratic procedures can impede the involvement and help of individual staff. Second, the way local governments manage their assets creates a major impediment: seeking to evade any kind of impression of giving away their assets under market price, deprive them of the flexibility necessary to support collaborative schemes. Third, collaborative housing is not seen as a phenomenon that has obvious qualities to the public, thus there is no political pressure on local municipalities to be engaged, and to

\footnotetext{
${ }^{7}$ Interviews were conducted in the course of the years 2015, 2016 and 2017.

${ }^{8}$ The municipal housing stock, as a result of privatis ation, is typically scattered in different buildings, with social housing being in dilapidated buildings mostly. Very few municipalities construct new dwellings.
} 
support it. Moreover, the nature of collaborative planning process requires engaging with a diverse group of actors on a more-or-less equal basis. However, local governments in Hungary seem to follow a significantly more traditional way of governing, preferring a top-down approach and less engagement with different stakeholders (Szemző, 2017). And finally, there is a prevalent lack of information on the possible positive role collaborative projects can play in providing public or private investors' housing with social/public purposes. Hence, local governments are not informed about the possible positive effects of collaborative housing projects.

\section{c. United Kingdom}

The collaborating housing scene in the UK is vastly different from the German or the Hungarian one: bottom-up initiatives are wide spread and local governments have embraced many of the participatory methods. Nonetheless, the environment is not supportive on all levels. Local governments (councils) would be crucial in this to support the initiatives, but they waiver sometimes. Although it is hard to talk about a single local government model in the UK considering their various form such as county councils, district councils, unitary authorities, metropolitan disctrics or London boroughs, local governments are responsible for strategic planning and housing in their jurisdiction.

With support from various actors collaborative housing has the potential to be a high growth sector in the UK (Baborska-Narozny et al., 2014) and there are suggestions that collaborative housing could be offered as an alternative to the traditional model of housing development. (Jarvis, 2011; Williams, 2005; Fenster, 1999). Furthermore, the growth of this sector is also propelled by the need and interest in special arrangements, like senior co-housing that seeks an alternative to living alone but rejects conventional forms of institutional housing for the elderly (Scanlon and Arrigoitia, 2015). Importantly, the autonomous structure of collaborative housing resonates with the current government policy of localism and decentralisation. Yet many local authorities have not given any substantial support for the development of collaborative housing. This situation is in contrast with the fact that there has been a number of political movements and statutory legislations that create favourable conditions for the development of collaborative housing in recent years. Statistical data is hard to get, but currently the number of co-housings is estimated to be 21 with 51 developing initiatives. $^{9}$

While there has been a strong endorsement from the government through policy and funding, there is still no commitment to provide land for collaborative housing development. As a result, housing projects struggle to find permissible land for new development. In this context, local authorities play an important role in providing support during planning permission and access to available land. The case of Lancaster co-housing (see in detail in the annex) is an example where the support of local authority is critical for the development of collaborative housing. While there is an increasing trend of top-down policies in supporting the development of collaboration, the reality is far from ideal for a group of people willing to start any collaborative housing project. The key obstacles include access to suitable lands, availability of

${ }^{9}$ https://cohousing.org.uk/information/uk-cohousing-directory/ 
financial instruments, lack of profile for the self-build industry and the lack of common method in calculating risk and viability.

Like typical collaborative housing project, Lancaster co-housing (LCH) is a housing development that balances the advantages of home ownership with the benefits of shared facilities and strong communities. LCH followed the usual processes such as in obtaining planning permission and building regulations approval. One of the difficulties is the fact that the process of getting planning permission can be very complex. In the UK, planning permission should also consider recommendations from different stakeholders such as Parish Council. The Parish Council is a civil local authority in England and is the lowest tier of local government. LCH faced several challenges in getting the approval from the Parish Council as they concern about potential disruptions on the existing infrastructure. For instance, they required $L C H$ to divert two public footpaths that go across $L C H$ 's land during construction. Other issues such as street lighting, parking places, and the impact of new roads and road widening were also discussed. Moreover, the consent of the Parish council is required for diversion or discontinuation of highway, traffic signs, tree planting and verge maintenance. While dealing with the Parish Council is not the only hurdle that LCH must deal with, there were some other challenges in relation to obtain planning permission from the local authority.

Supporting collaborative housing initiatives would require an unorthodox approach from local governments, who are currently hardly incentivised nor rewarded for meeting strategic house building needs. While there is a call for local authorities to provide the necessary professional advice to collaborative housing projects, funding for such service may not available in many local authorities' budgets. Local authorities may encourage the role of intermediaries such as housing associations or successful collaborative housing projects, to provide support on the early stage of new co-housing projects. This includes more practical help in planning permission such as simplifying the process and providing clear targets for the time it takes to get planning permission. However, without an increase in public awareness regarding the merits of collaborative housing project, it is very difficult to attract the intermediaries and the complexity in obtaining planning permission may still slow down the process and potentially inhibit new initiatives.

For collaborative housing projects, support is especially critical in the early stages of a project, from formation of a group to the planning stage. Unfortunately, due to strong financial constraints, local authorities are not able to meet the demand for this service. Assisting a small group such as collaborative housing project is not feasible within their budget. In some cases, local authorities may favour projects that likely to develop the largest number of homes. There is also a strong sense of low levels of public awareness. This situation led to a lack of understanding of the potential of collaborative housing project. Other institutions or organisations such as Parish Council or bank/lender encounte difficulties in assessing the demand (or potential demand) of collaborative housing projects. On some occasion, there is a misunderstanding between local authority on the motivation and importance of supporting collaborative housing project as a part of a bigger effort to solve the undersupply of new housing. 


\section{Conclusion: remarks and lessons}

In this contribution, we compared the conditions in three countires for successful creation of collaborative housing projects. It was shown that the success rate depends on the complex interplay of legal, institutional and financial factors, in which local governments are crucial players. Their role is complicated, as collaborative housing is situated between the private and public interests in housing provision, often without a concrete line of division between the two spheres. This creates a situation where the role of public entities becomes harder to define and articulate. Sometimes, identifying what is of public interest becomes diffuse and difficult to answer. For example, core ideas of solidarity, environmental protection and sharing seem to be especially important in community-oriented co-housing initiatives, while they might not be as prevalent in more business oriented co-building initiatives/construction groups. Nevertheless, even projects without a clear social integrative function, can be of public interest as a result of effects on urban development or their core values regarding the environment and energy use.

The interaction between local governments and collaborative housing groups takes place in the housing arena in which public and private actors have their exclusive roles. This creates tgovernance schemes that regulate the way private and public interests are represented and supported. The governance schemes and the role of local governments are different in the three countries of study. While in each case local governments have substantial role in housing either through social housing provision, spatial planning or as a regulatory body, their approach towards collaborative housing projects is strongly determined by a culture of openness to engage in more participatory processes with local residents and a willingness to do it on an equal footing. Another important factor is to what extent local governments think these projects contribute to their priorities, be it housing, urban development or environmental goals. In case local governments see collaborative housing as providing additional values and these values fit to their value map they can be instrumental in its support (Moore and Khagram 2004).

In all three countries, local governments theoretically possess the rights and the instruments to encourage the creation of new collaborative housing projects to a great extent. However, only in Germany are they willing to wholeheartedly engage in a dialogue with various groups and create a transparent process. Here local government can provide land/empty building under preferential conditions, provide information or coaching for the potential participants of collaborative projects and ease the process of loan acquisition from banks. These actions that can all be observed among many German local governments. Also many of them have taken up new roles following a change in governance model, and negotiate with residents as partners, as well as create a supporting stakeholder environment. In numerous German local governments collaborative housing thus has become a way to achieve their social and urban development goals.

This is not at all the case in Hungary, where local governments are still engaged in a top-down relationship, a tendency, which has been strengthened by the centralisation processes of the last years. Also, the Hungarian case showed that the lack of transparency hinders possible negotiations, and other possibilities to work with residents in a bottom-up way. The lack of intermediaries and the conservative lending 
practices of the banks do not help either. Although the idea of collaborative housing can seem interesting for local governments, this general interest is easily lost on the way, as local governments are not regarding housing provision as central task, and there is little national funding available to help them. It takes extraordinary determination from collaborative housing groups - like the Rákóczi Kollektíva- to initiate still this process, and also to realise an actual building.

Finally, in this context the UK seems to be on the middle-ground: whereas there is a central governmental push towards decentralised initiatives, the lack of resources works against their realisation. Another possible explanation for this lack of support is that some local governments do not recognise the external benefits of collaborative housing projects. In this case, co-housing projects are handled in the same way as any general housing project and instead of a participatory approach, a classical governmental approach will dominate the relationship. As the example of Lancaster co-housing showed, such an approach may lead to tensions in the process. This approach can also lead to limitations in the success of collaborative projects: while the wealthier and better educated members of society will be able to finance and organise collaborative projects in order to meet regular requirements of a construction processes, possible participation for less affluent groups is limited. In short: without collaboration with local authorities, the failure rate of newly emerging projects is likely to increase, whereas applying instrumetns such as land allocation and funding security not only increases the number of projects but also contributes to local agenda's for urban development

Acknowledgements

Hanna Szemző and Éva Gerőházi would like to thank the Rákóczi Kollektíva, especially Csaba Jelinek and Zsuzsanna Pósfai for their help in providing information and pictures for the Hungarian case study.

\section{References}

Abers, Rebecca. 1998. "From Clientelism to Cooperation: Local Government, Participatory Policy, and Civic Organizing in Porto Alegre, Brazil." Politics \& Society 26 (4): 511-537.

Ache, Peter, and Micha Fedrowitz. 2012. "The Development of Co-Housing Initiatives in Germany." Built Environment 38 (3): 395-412.

Ansell, Chris, and Alison Gash. 2007. "Collaborative Governance in Theory and Practice." Journal of Public Administration Research 18:543-571.

BBSR, ed. 2016. Wohnungsgenossenschaften als Partner der Kommunen: Bündnis für bezahlbares Wohnen und Bauen. Bonn: Bundesinstitut für Bau-, Stadt- und Raumforschung.

BMVBS, and BBR, eds. 2007. Erschließen von Genossenschaftspotenzialen. Forschungen, Heft 126. Bonn: Bundesamt für Bauwesen und Raumordnung.

Beaumont, Justin and Walter Nicholls. 2008. "Plural Governance, Participation and Democracy in Cities." International Journal of Urban and Regional Research 32 (1): 87-94. 
Bresson, Sabrina, and Anne Labit. 2017. "French Collaborative Housing: Toward New Partnerships Promoting Affordability and Social Inclusion?" Paper presented at the ENHR conference, September 4-6, 2017.

Boelens, Luuk, and Anne-Jo Visser. 2011. "Possible Futures of Self-construction: Poststructural Reflections on Ten Years of Experimentation with (C)PC." In Making room for people: choice, voice and liveability in residential places, edited by Lei Qu and Evert Hasselaar, 103-128. Amsterdam: Techne Press.

Boonstra, Beitske 2015. "Planning strategies in an age of active citizenship: a poststructuralist agenda for self-organization in spatial planning" -thesis, University of Ghent, January 2015

Czischke, Darinka. 2017. "Collaborative Housing and Housing Providers: Towards an Analytical Framework of Multi-Stakeholder Collaboration in Housing CoProduction.” International Journal of Housing Policy, DOI: 10.1080/19491247.2017.1331593.

Czischke, Darinka, and Carla J. Huisman. 2018. "Integration through Collaborative Housing? Dutch Starters and Refugees Forming Self-Managing Communities in Amsterdam." Urban Planning. DOI: http://dx.doi.org/10.17645/up.v3i4.1727

Droste, Christiane. 2015. "German Co-Housing: An Opportunity for Municipalities to Foster Socially Inclusive Urban Development?" Urban Research and Practice 8:79-92.

Fagotto, Elena, and Archon Fung. 2006. "Empowered Participation in Urban Governance: The Minneapolis Neighbourhood Revitalization Program." International Journal of Urban and Regional Research 30 (3): 638-655.

Ferencz, Zoltán. 2015 "A társadalmi részvétel és a nagyvárostérségi versenyképesség” (Public participation and the metropolitan competitiveness). In A területi egyenlőtlenségektől a társadalmi jól-lét felé (From spatial segregation towards social well-being) edited by Viktória Szirmai. Kodolányi János Főiskola, Székesfehérvár, pp. 327-349.

Gerőházi, Éva and József Hegedüs. 2016. "SME network business model and ESCO business plan for new district development." Unpublished report,

PROFICIENT Project, www.proficient-project.eu.

Hartmann, Julia, and Axel Burkhardt. 2017. “Tübingens Non-profit Oriented Housing Development. Sustainable Housing Provision: Concept-Based, Fixed Price Land Allocation." In Self-organized, Community-led Housing for All, edited by Michael LaFond and Larisa, 144-146. Tsvetkova. Berlin: Jovis.

Hegedüs, József. 2013. "Unorthodox Housing Policy in Hungary - Is There a Way Back to Public Housing?" In The Future of Public Housing: Ongoing Trends in the East and the West, edited by Jie Chen, Mark Stephens, Joyce Yanyun Man, 259278. Heidelberg: Springer.

Hegedüs, József, and Hanna Szemző. 2015. "The Role of Housing Assets in Shaping the New Welfare Regime in Transition Countries: The Case of Hungary." Critical Housing Analysis 2 (1): 82-90.

Jakobsen, Peter, and Henrik Gutzon Larsen. 2018. "An alternative for whom? The evolution and socio-economy of Danish cohousing." Urban Research \& Practice, DOI: 10.1080/17535069.2018.1465582Kott, Kristina et al. 2016. 
"Wohnen." In Datenreport 2016, edited by Statistisches Bundesamt and Wissenschaftszentrum Berlin für Sozialforschung, 259-273. Bonn: Bundeszentrale für politische Bildung

LaFond, Michael, and Larisa Tsvetkova, eds. 2017. CoHousing Inclusive: Selbstorganisiertes, gemeinschaftliches Wohnen für alle / Self-organized, Community-led Housing for All. Berlin: Jovis (under publication).

Lang, Richard, Claire Carriou, Darinka Czischke. 2018. "Collaborative Housing Research (1990-2017): A Systematic Review and Thematic Analysis of the Field." Housing, Theory and Society. DOI 10.1080/14036096.2018.1536077

Lang, Richard, and David Mullins. 2015. Bringing Real Localism into Practice Through Co-Operative Housing Governance: The Role and Prospects for CommunityLed Housing in England. Housing and Communities Research Group WP1$2015 . \quad$ University of Birmingham. http://www.birmingham.ac.uk/Documents/college-social-sciences/socialpolicy/IASS/housing/2015/working-paper-series/HCR-WP-1-2015.pdf

Lang, Richard, and Harald Stoeger. 2017. "The role of the local institutional context in understanding collaborative housing models: empirical evidence from Austria." International Journal of Housing Policy 17: 1-20.

Lehrstuhl für energieffizientes und nachhaltiges Planen und Bauen der Technischen Universität München. 2017. Gemeinschaftlich nachhaltig bauen Forschungsbericht der ökologischen Untersuchung des genossenschaftlichen Wohnungsbauprojektes wagnisART. München: Oberste Oberste Baubehörde im Bayerischen Staatsministerium des Innern, für Bau und Verkehr.

Moore, Mark, and Khagram Sanjeev. 2004. On Creating Public Value: What Business Might Learn from Government about Strategic Management. Corporate Social Responsibility Initiative Working Paper No. 3. Cambridge, MA John F. Kennedy School of Government, Harvard University. https://sites.hks.harvard.edu/mrcbg/CSRI/publications/workingpaper_3_moore_khagram.pdf

Moore, Tom, and Kim McKee. 2014. "The Ownership of Assets by Place-Based Community Organisations: Political Rationales, Geographies of Social Impact and Future Research Agendas," Social Policy and Society 13: 521-533.

Netzwerk Selbsthilfe. 2010. Zukunft Quartier - Lebensräume zum Älterwerden. Volume 3. Gütersloh: Bertelsmann-Stiftung.

Ring, Kristin. 2016. "Wagnis 3, Munich." In Building and Living in Communities: Ideas, Processes, Architecture, edited by Annette Becker et al., 62-67. Basel: Birkhäuser.

Scanlon, Kathleen, and Melissa Fernandez Arrigoitia. 2015. "Development of New CoHousing: Lessons from a London Scheme for the Over 50s." Urban Research and Practice 8: 106-121.

Sorensen, André, and Lake Sagaris. 2010. "From Participation to the Rights to the City? Democratic Place Management at the Neighbourhood Scale in Comparative Perspective." Planning Practice and Research 25: 297-316. 
Scheller, David, and Håkan Thörn Governing. 2018. "Sustainable Urban Development' Through Self-Build Groups and Co-Housing: The Cases of Hamburg and Gothenburg." International Journal of Urban and Regional Research 42 (5): 914-933.

Szemzö, Hanna. 2017. "Caught between the Public and the Private: Urban Cooperative Solutions in Central Europe." In Funding the Cooperative City: Community Finance and the Economy of Civic Spaces, edited by Daniela Patti and Levente Polyak. Vienna: Cooperative City Books.

Swyngedouw, Erik. 2000. Authoritarian Governance, Power and the Politics of Rescaling, Environment and Planning D: Society and Space 18: 63-76.

Tummers, Lidewij. 2015a. "The Re-Emergence of Self-Managed Co-Housing in Europe: A Critical Review of Co-Housing Research." Urban Studies 53 (10): 2023-2040.

Tummers, Lidewij. 2015b. "Understanding Co-Housing from a Planning Perspective: Why and How?" Urban Research and Practice, 8:64-78.

Twardoch, Agata. 2017. "Collaborative housing perspectives. Definition, historical overview and examples." Architecture Civil Engineering Environment 10 (4): 33-44.

Verstraete, Jana, and Pascal De Decker. 2017. "Innovative Housing Initiatives in Belgium. Filling the Gap to Realize the Right to Housing? An Analysis of Similarities and Differences Between two Waves of Initiatives." Paper presented at the ENHR conference, September 4-6.

Williams, Jo. 2005. Sun, Surf and Sustainable Housing-Cohousing, the Californian Experience. International Planning Studies 10 (2): 145-177. 